\title{
Juotto- ja vieroitusstrategioiden vaikutukset maitorotuisten vasikoiden kasvuun, terveyteen ja hyvinvointiin
}

\author{
Leena Tuomisto ja Arto Huuskonen \\ Maa- ja elintarviketalouden tutkimuskeskus, Kotieläintuotannon tutkimus, Tutkimusasemantie 15, \\ 92400 Ruukki,leena.tuomisto@mtt.fi, arto.huuskonen@mtt.fi
}

\section{Tiivistelmä}

Tämän kirjallisuuskatsauksen tavoitteena oli selvittää juottomäärän ja vieroitusstrategioiden vaikutuksia maitorotuisten vasikoiden kasvuun, terveyteen, hyvinvointiin sekä myöhempään tuotokseen. Kirjallisuuden perusteella vasikoille tulisi tarjota runsaasti juomaa (maitoa tai juomarehua vähintään 7,5 1/vrk). Runsaasti (vähintään 7,5 1/vrk) juotetut vasikat kasvavat juottokaudella paremmin kuin niukasti (4,0-6,0 1/vrk) juotetut vasikat. Runsaan juoton haittana on kuitenkin kiinteän rehun vähäinen syönti juottokaudella. Runsaasti juotettujen vasikoiden energian saanti yleensä pienenee vieroituksen yhteydessä, koska maidon tai juomarehun määrä vähenee nopeammin kuin kiinteän rehun syönti kasvaa. Tämä näkyy tavallisesti kasvun väliaikaisena taantumisena.

Juottomäärän ei useimmissa tutkimuksissa ole havaittu vaikuttavan vasikoiden terveyteen. Niukalla juotolla vasikat vierailevat useammin tuloksetta (vasikalla ei ole voimassa olevaa juontioikeutta) juottoautomaatilla, viettävät kaikkiaan juottoautomaatilla enemmän aikaa ja häiritsevät juovaa eläintä useammin kuin runsaalla juotolla. Nämä käyttäytymismuutokset viittaavat siihen, että vasikat jäävät nälkäisiksi niukalla juotolla. Juottoautomaatin kapasiteetti pystytään hyödyntämään parhaiten juottamalla vasikoita runsaasti, jolloin yksittäisen vasikan juottoautomaatilla viettämä aika lyhenee. Juottokauden hyvällä ravitsemuksella ja kasvulla on muutamissa kokeissa havaittu myönteisiä vaikutuksia hiehojen tuotokseen ensimmäisellä tuotoskaudella. Tosin useissa muissa kokeissa vastaavaa yhteyttä ei ole todettu. Hyvin niukan juoton (juomarehua 4 1/vrk) on todettu heikentävän sonnien elinikäiskasvua.

Tuotanto-oloissa vieroitus on mahdollinen stressin lähde, koska maidolta tai juomarehulta vieroitus tapahtuu aiemmin ja nopeammin kuin luonnossa. Asteittainen vieroitus juoman määrää vähentämällä kannustaa vasikoita väkirehun syöntiin. Nuoret vasikat eivät kuitenkaan pysty täysin kompensoimaan maidon juonnin vähenemistä väkirehun syöntiä lisäämällä, mikä näkyy kasvun taantumisena. Asteittainen vieroitus on kuitenkin parempi vieroitustapa kuin äkillinen vieroitus. Runsaasti juotetut vasikat voivat hyötyä portaittaisesta vieroituksesta, joka tapahtuu laimentamalla maitoa vedellä. Vieroitukseen liittyvää stressireaktiota voidaan lieventää tarjoamalla vasikalle edelleen pääsy juottolaitteelle juomaan lämmintä vettä muutaman päivän ajan vieroituksen jälkeen. Varhainen, kuuden viikon iässä tapahtuva vieroitus vaarantaa vasikoiden hyvinvoinnin. Kuuden viikon iässä tapahtuvassa vieroituksessa vasikoiden kasvu heikkenee, juoksuleikki vähenee ja nälästä kertova käyttäytyminen lisääntyy. Runsaasti juotetut vasikat hyötyvät vieroituksen lykkäämisestä 12-13 viikon ikään, koska myöhäinen vieroitus parantaa kiinteän rehun syöntiä ja kasvua ja vähentää nälästä kertovaa käyttäytymistä vieroituksen aikana. On kuitenkin todennäköistä, että vieroittaminen hieman aiemmin, noin kymmenen viikon iässä, ei vaaranna vasikoiden hyvinvointia.

Asiasanat: vasikat, juottomäärä, vieroitus, kasvu, terveys, käyttäytyminen, hyvinvointi 


\section{Johdanto}

Vasikka voi ensimmäisten elinviikkojensa aikana hyödyntää lähinnä juoman mukana saamiaan ravintoaineita. Monissa yhteyksissä on havaittu, että vieroitusvaihe muodostuu usein vasikoille ongelmakohdaksi. Tämän kirjallisuuskatsauksen tavoitteena oli selvittää juottomäärän ja juotolta vieroitusstrategioiden vaikutuksia vasikoiden kasvuun, terveyteen ja hyvinvointiin. Lisäksi kartoitettiin juottoruokinnan toteutuksen mahdollisia pitkäaikaisvaikutuksia myöhempään tuotokseen.

\section{Juottokäytännöt}

Tavanomaisessa maidontuotannossa vasikat erotetaan tyypillisesti emoistaan vuorokauden kuluessa syntymästä ja ruokitaan rajoitetulla määrällä maitoa tai teollista juomarehua (Jasper \& Weary 2002). Pohjois-Amerikassa tavallinen päiväannos juomaa on noin 8-15\% vasikan elopainosta (Borderas ym. 2009), jolloin $40 \mathrm{~kg}$ painoinen vasikka saa kaksi noin 2-3 litran suuruista juoma-annosta vuorokaudessa. Suomessa vasikoita suositellaan juotettavaksi runsaammin, vähintään 7-8 1/vrk tai vapaasti (Kemppi 2005). Juomista rajoittamalla pyritään rohkaisemaan vasikoita kiinteän rehun syöntiin mahdollisimman varhain ja estämään kasvun hidastumista vieroituksen yhteydessä (Khan ym. 2011). Vieroituksen ajankohdassa on suurta vaihtelua. Pohjois-Amerikassa vasikat vieroitetaan maitotiloilla yleisesti 6-8 viikon iässä (Vasseur ym. 2010). Suomessa vasikka suositellaan vieroitettavaksi 8-9 viikon iässä sen syödessä vähintään kilogramman väkirehua päivässä (Kemppi 2005). Luomutuotannossa vasikoiden ruokavalion tulee sisältää maitoa vähintään kolmen kuukauden ikään (Evira 2013).

\section{Juottomäärän vaikutus vasikan kasvuun, rehun syöntiin ja terveyteen}

Vasikat juovat vapaasti juotettuina suuria määriä maitoa tai juomarehua. Vapaasti juotettujen vasikoiden juoman kulutukseksi on mitattu 8-10 1/vrk (Budzynska \& Weary 2008, Borderas ym. 2009, Sweeney ym. 2010, de Passillé ym. 2011). Myöhään vieroitettavien vasikoiden juoman kulutus on vieläkin suurempi, 10-11 1/vrk (de Passillé ym. 2011). Juomamäärät vastaavat vasikoiden emoistaan imemää maitomäärää, sillä vasikoiden on mitattu imevän maitoa emoistaan $6,5 \mathrm{~kg} / \mathrm{vrk}$ ensimmäisellä elinviikollaan ja 12,5 kg/vrk yhdeksännellä elinviikollaan (de Passillé ym. 2008).

Vapaasti tai runsaasti (7,5-10,0 1/vrk) juotetut vasikat kasvavat juottokaudella paremmin kuin niukasti (4,0-6,0 1/vrk) juotetut vasikat (Khan ym. 2007, Huuskonen \& Khalili 2008, Nielsen ym. 2008a, Borderas ym. 2009, de Passillé ym. 2011, Fröberg ym. 2011). Juoman määästä riippumatta vasikoiden syömän väkirehun määrä on pieni ensimmäisten 2-4 elinviikon ajan (Appleby ym. 2001, Borderas ym. 2009, Fröberg ym. 2011). Siten nuorimpien vasikoiden on niukalla juotolla vaikea kompensoida vähäistä maidon saantia väkirehun syöntiä kasvattamalla. Vapaasti tai runsaasti juotettujen vasikoiden hyvä kasvu juottokaudella onkin seurausta ravintoaineiden suuremmasta saannista niukasti juotettuihin vasikoihin verrattuna.

Vapaan tai runsaan juoton haittana on kiinteän rehun vähäinen syönti juottokaudella (Jensen 2006, Nielsen ym. 2008a, Morrison ym. 2009, de Passillé ym. 2011, Fröberg ym. 2011). Vieroituksessa vapaasti tai runsaasti juotettujen vasikoiden energian saanti yleensä pienenee, koska maidon tai juomarehun määrä vähenee nopeammin kuin kiinteän rehun syönti kasvaa. Vieroituksen yhteydessä tai sen jälkeen kasvuerot tavallisesti tasoittuvat runsaasti ja niukasti juotettujen vasikoiden välillä (Jensen 2006, Morrison ym. 2009, de Passillé ym. 2011, Huuskonen ym. 2011). Vieroituksen jälkeen myös erot väkirehun syönnissä runsaasti juotettujen ja niukasti juotettujen vasikoiden välillä tasoittuvat väkirehun syöntikyvyn kehittyessä (Jasper \& Weary 2002, Jensen 2006, Huuskonen ym. 2011).

Useissa tutkimuksissa vapaasti tai runsaasti ja niukasti juotettujen vasikoiden välillä ei ole havaittu eroa ripulin tai hengitystiesairauksien (Jasper \& Weary 2002, De Paula Vieira ym. 2008, Borderas ym. 2009) määrässä. Joissakin tutkimuksissa runsaammin juotetuilla vasikoilla esiintyi ajoittain jopa vähemmän ripulia kuin niukemmin juotetuilla vasikoilla (Appleby ym. 2001, Khan ym. 2007). Quigley ym. (2006) raportoivat päinvastaisesta tuloksesta: ripulia esiintyi vähemmän niukasti juotetuilla vasikoilla kuin runsaammin ja pidempään juotetuilla vasikoilla.

\section{Juottomäärän vaikutus juottoautomaatin käyttöön}

Vasikat vierailevat useammin tuloksetta (vasikalla ei ole voimassa olevaa juontioikeutta) juottoautomaatilla niukalla juotolla kuin vapaalla tai runsaalla juotolla: 35 vs. 15 käyntiä/vasikka/vrk (Jensen 2006), 24 vs. 2 käyntiä/vasikka/vrk (De Paula Vieira ym. 2008) ja 28 vs. 11 käyntiä/vasikka/vrk (Niel- 
sen ym. 2008a). Myös de Passillé ym. (2011) raportoivat tuloksettomien juottoautomaattikäyntien suuresta määrästä niukasti juotetuilla vasikoilla. Tuloksettomia juottoautomaattikäyntejä, etenkin niiden esiintyessä suuressa määrin, pidetään merkkinä vasikoiden nälästä tai voimakkaasta syömismotivaatiosta (Jensen 2006, De Paula Vieira ym. 2008).

Tuloksettomista juottoautomaattikäynneistä johtuen vasikat viettävät enemmän aikaa juottoautomaatilla niukalla juotolla kuin vapaalla tai runsaalla juotolla: 51 vs. $42 \mathrm{~min} / \mathrm{vasikka/vrk}$ (Jensen 2006), 122 vs. $66 \mathrm{~min} /$ vasikka/vrk (De Paula Vieira ym. 2008) ja 31-77 vs. 26-41 min/vasikka/vrk (Borderas ym. 2009). Siten niukkaa juottoa käytettäessä juottoautomaatti pystyy juottamaan pienemmän määrän vasikoita kuin vapaata tai runsasta juottoa käytettäessä. De Paula Vieira ym. (2008) havaitsivat vasikoiden puskevan useammin juottoautomaatilla ollutta vasikkaa niukalla kuin vapaalla juotolla. Monet näistä kontakteista johtivat juomassa olleen vasikan syrjäytykseen. Niukasti juotetuilla vasikoilla juottoautomaatti oli suuremman osan ajasta varattuna, mikä mahdollisesti selitti kilpailun suurta määrää. Juottoautomaatin kapasiteetti pystytäänkin hyödyntämään parhaiten juottamalla vasikoita runsaasti, jolloin vasikoiden juottoautomaatilla viettämä aika lyhenee ja juottoautomaatti pystyy juottamaan suuremman määrän vasikoita. Mikäli vasikoiden juottoautomaatilla viettämää aikaa pyritään rajoittamaan muilla keinoin, esimerkiksi lyhentämällä juoma-ajan kestoa (Morita ym. 1999), vaarana on imemismotivaation jääminen tyydyttymättä ja toiseen eläimeen kohdistuvan imemisen lisääntyminen (Jung \& Lidfors 2001).

\section{Juottomäärän vaikutukset eläimen myöhempään tuotokseen}

Tutkimustulokset vasikan juottomäärän vaikutuksista eläimen myöhempään tuotokseen ovat osittain ristiriitaisia. Juottokauden vapaan tai runsaan juoton on todettu vaikuttavan myönteisesti hiehon ensimmäisen tuotoskauden maitotuotokseen (Bar-Peled ym. 1997, Drackley ym. 2007), rasvakorjattuun maitotuotokseen (Shamay ym. 2005) ja valkuaistuotokseen (Shamay ym. 2005, Drackley ym. 2007), kun vertailukohtana on ollut niukka juotto. Runsaammin juotetut vasikat ovat myös poikineet aiemmin kuin niukasti juotetut vasikat (Bar-Peled ym. 1997, Davis Rincker ym. 2006, Raeth-Knight ym. 2009).

Toisissa tutkimuksissa juottomäärän ei ole havaittu vaikuttavan hiehojen ikään ensimmäisessä siemennyksessä (Aikman ym. 2007), tarvittavien siemennyskertojen määrään (Aikman ym. 2007), hiehojen ikään ensimmäisessä poikimisessa (Aikman ym. 2007, Drackley ym. 2007, Morrison ym. 2009), hiehojen säkäkorkeuteen ja kuntoluokitukseen poikimisen yhteydessä (Davis Rincker ym. 2006), poikimisen helppouteen (Davis Rincker ym. 2006) tai hiehojen kokoon ensimmäisessä poikimisessa (Bar-Peled ym. 1997, Morrison ym. 2009). Juottomäärä ei myöskään ole vaikuttanut vasikan syntymäpainoon (Davis Rincker ym. 2006), maitotuotokseen ensimmäisellä tuotoskaudella (Foldager \& Krohn 1994, Aikman ym. 2007, Morrison ym. 2009, Raeth-Knight ym. 2009), maidon rasva- ja proteiinipitoisuuteen ensimmäisellä tuotoskaudella (Foldager \& Krohn 1994), maidon rasvatuotokseen ensimmäisellä tuotoskaudella (Bar-Peled ym. 1997, Drackley ym. 2007), maidon valkuaistuotokseen ensimmäisellä tuotoskaudella (Bar-Peled ym. 1997), maidon koostumukseen ensimmäisellä tuotoskaudella (Morrison ym. 2009) tai hiehojen utarekudoksen koostumukseen tai kehitykseen (Daniels ym. 2009). Juottomäärän ei ole havaittu vaikuttavan myönteisesti lehmien ikään toisessa poikimisessa (Aikman ym. 2007), toisen tuotoskauden maitotuotokseen (Morrison ym. 2009) tai maidon koostumukseen toisella tuotoskaudella (Morrison ym. 2009).

Naudanlihantuotannon osalta juottomäärän vaikutuksia eläimen myöhempään tuotokseen on tutkittu vähemmän kuin maidontuotannossa. Steenin (1991) tutkimuksessa juottomäärällä (vapaa vs. 4 1/vrk) ei ollut vaikutusta lihanautojen kasvuun vieroituksen jälkeen, teurastuloksiin tai teuraspainoon. Myöskään erilaisilla hapanjuottostrategioilla (vapaa juotto 18 viikon ikään, rajoitettu juotto 10 viikon ikään) ei havaittu vaikutusta lihanautojen elinikäiskasvuun tai teurastulokseen (Khalili ym. 2004).

Huuskonen ym. (2011) vertasivat erilaisia luomujuottostrategioita ja niukkaa juottoa (juomarehua 4 1/vrk) ja selvittivät lihantuotantoa varten kasvatettujen maitorotuisten vasikoiden elinikäistuotosta. Hapatetulla maidolla juotettujen (10 tai 61 , vieroitus 90 vrk iässä) vasikoiden elinikäiskasvuissa ei ollut eroa ryhmien välillä, mutta niukalla juomarehujuotolla olleet vasikat kasvoivat elinaikanaan heikommin ja olivat teuraspainoltaan kevyempiä kuin maidolla juotetut vasikat. Niukka juotto (juomarehua 4 l/vrk, vieroitus 60 vrk iässä) oli siten riittämätön turvaamaan samankaltaisen elinikäiskasvun kuin edellä kuvatut hapanmaitojuottostrategiat. Käsittelyjen välillä ei ollut eroa ruhojen lihakkuudessa tai rasvaisuudessa. 


\section{Vieroitusmenetelmät}

Luonnossa lehmä vieroittaa vasikkansa lopullisesti vasta noin 10 kuukauden iässä. Tuotanto-oloissa vieroitus on mahdollinen stressin lähde, koska maidolta tai juomarehulta vieroitus tapahtuu aiemmin ja nopeammin kuin luonnossa. Maidolta tai juomarehulta vieroittaminen voidaan suorittaa monella tavalla. Äkillisessä vieroituksessa maidon juottaminen lopetetaan kerralla. Asteittaisessa vieroituksessa juoman määrää vähennetään vähitellen useiden päivien aikana tai maitoa laimennetaan vähitellen vedellä useiden päivien aikana. Tarkoituksena on sopeuttaa vasikat vähitellen maidosta saatavan energian vähenemiseen ja kannustaa vasikoita väkirehun syömiseen. Laimennusmenetelmällä vasikat voivat läpi vieroituksen käyttää edelleen juottolaitetta imemiseen, koska menetelmässä tarjotaan nestettä juottolaitteesta vieroituksen aikana sama määrä kuin juoton aikana (Nielsen ym. 2008b).

Perinteisesti vieroitusajankohdan perusteena on käytetty vasikan ikää. Vieroitus voidaan myös ajoittaa vasikan väkirehun syöntimäärän kehityksen mukaan, koska vasikoiden kyvyssä sopeutua kiinteälle rehulle esiintyy suurta yksilöllistä vaihtelua (De Passillé \& Rushen 2012). Automaattisia ruokintalaitteita käytettäessä vieroitus voidaan toteuttaa yksilöllisesti kunkin vasikan alkukasvatusrehun syöntimäärän kehittymisen perusteella. Väkirehun syöntiin perustuvassa vieroituksessa juoman määrää vähennetään yksilöllisesti suhteessa väkirehun syöntiin (Roth ym. 2009b). Menetelmän tarkoituksena on kattaa vasikan ravitsemukselliset tarpeet missä tahansa juoton vaiheessa ja varmistaa, että vasikkaa ei vieroiteta maidolta ennen kuin vasikka on valmis syömään ainoastaan kiinteää rehua.

\section{Asteittainen vieroitus juoman määrää vähentämällä}

Asteittainen vieroitus juoman määrää vähentämällä voidaan suorittaa vähentämällä juoma-annosten lukumäärää annoksen koon pysyessä vakiona, pienentämällä annoksen kokoa annosten lukumäärän pysyessä vakiona tai molempien tapojen yhdistelmänä (Jensen 2006). Vieroitustapoja vertailtaessa selvisi, että asteittainen vieroitus annoksen kokoa pienentämällä voi olla parempi vieroitustapa kuin asteittainen vieroitus annosten lukumäärää vähentämällä (Jensen 2006). Vasikoiden vieroitus 52-68 päivän iässä annosten lukumäärää vähentämällä johti tuloksettomien juottoautomaattikäyntien (vasikalla ei voimassaolevaa juontioikeutta) suurempaan määrään ja nopeampaan juoman juomiseen. Vieroitustavalla ei kuitenkaan ollut vaikutusta vasikoiden kasvuun.

Sweeney ym. (2010) vertasivat runsaasti juotettujen vasikoiden asteittaista vieroitusta 22, 10 tai 4 päivän ajalla ja äkillistä vieroitusta. Kaikilla käsittelyillä vieroitus päättyi vasikoiden 41 päivän iässä. Asteittainen vieroitus lisäsi väkirehun syöntiä, mutta vasikat eivät pystyneet täysin kompensoimaan juonnin vähenemistä väkirehun syönnillä, mikä näkyi kasvun heikkenemisenä vieroituksessa. Kasvu kärsi etenkin vasikoilla, joiden vieroitus alkoi varhaisimmin ja kesti 22 päivää. Äkillisesti vieroitetut vasikat myös menettivät painoaan vieroituksen jälkeisinä päivinä. Parhaan kasvutuloksen saavuttivat vasikat, joilla juoman määrää vähennettiin asteittain 10 päivän aikana. Muissakin tutkimuksissa runsaasti juotettujen vasikoiden kasvu on kärsinyt vieroituksen yhteydessä, vaikka vieroitus on toteutettu asteittain pienentämällä juoman määrää (Jensen 2006, Huuskonen \& Khalili 2008, Morrison ym. 2009).

Nielsen ym. (2008a) raportoivat runsaasti tai niukasti juotetuilla, 55 vrk iässä äkillisesti vieroitetuilla vasikoilla vieroituksen jälkeen useampia juottoautomaattikäyntejä ja pidemmän juottoautomaatilla vietetyn ajan kuin asteittain 42-55 vrk iässä vieroitetuilla vasikoilla. Tämä saattoi kertoa äkillisesti vieroitettujen vasikoiden näläntunteesta. Lisäksi äkillisesti vieroitetuilla vasikoilla esiintyi välittömästi vieroituksen jälkeen enemmän toisen eläimen imemistä. Energian saanti oli vieroituksen jälkeisellä viikolla suurempi asteittain vieroitetuilla vasikoilla kuin äkillisesti vieroitetuilla vasikoilla, mutta vieroitustavalla ei ollut tilastollisesti merkitsevää vaikutusta vasikoiden kasvuun.

\section{Asteittainen vieroitus juomaa laimentamalla}

Asteittaisella vieroituksella juomaa vedellä laimentamalla ei ole todettu etua tai haittaa niukasti juotettujen vasikoiden kasvulle (Jasper ym. 2008, Nielsen ym. 2008b). Väkirehun kulutukseen vieroitustapa sen sijaan on vaikuttanut. Jasper ym. (2008) vieroittivat vasikat kymmenen viikon iässä joko äkillisesti tai laimentamalla maitoa vedellä viiden päivän ajan. Laimentamalla vieroitetut vasikat kompensoivat pienentyvää energian saantia kaksinkertaistamalla väkirehun syönnin vieroituksen aikana. Vieroituksen jälkeen ryhmien välillä ei ollut eroa väkirehun kulutuksessa. Nielsen ym. (2008b) puolestaan havaitsivat väkirehun kulutuksen olevan merkitsevästi pienempi vieroituksen aikana ja suuntaa antavasti pienempi vieroituksen jälkeen laimentamalla vieroitetuilla vasikoilla kuin tavanomaisesti asteittain 
vieroitetuilla vasikoilla. Lisäksi laimentamalla vieroitetut vasikat makasivat vieroitusjaksolla vähemmän kuin tavanomaisesti asteittain vieroitetut vasikat. Vieroitustavalla ei ollut vaikutusta toisen eläimen imemisen määrään. Nielsen ym. (2008b) vieroittivat vasikat 47-56 vrk iässä asteittain vähentämällä maidon määrää tai laimentamalla maitoa vedellä juoman määrän pysyessä entisellään.

Budzynska \& Weary (2008) havaitsivat lämpimän veden tarjoamisen vieroituksen jälkeen lieventävän vieroitukseen liittyvää stressireaktiota. Vapaasti juotetut vasikat vieroitettiin 47 päivän iässä, jonka jälkeen osalle vasikoista tarjottiin kahden päivän ajan lämmintä vettä tutista. Kaikki vasikat reagoivat vieroitukseen ääntelemällä, mutta ääntelyä havaittiin vesiryhmän vasikoilla yli kolme kertaa vähemmän välittömästi vieroituksen jälkeen. Lisäksi vesiryhmän vasikoilla esiintyi harvempia seisomisjaksoja kuin vasikoilla, joille ei tarjottu lämmintä vettä vieroituksen jälkeen. Budzynska \& Weary (2008) sekä Jasper ym. (2008) esittivät, että vieroitukseen liittyvän stressireaktion lieveneminen tarjottaessa vasikoille lämmintä vettä vieroituksen jälkeen saattoi liittyä juottolaitteen mahdollistamiin käyttäytymistoimintoihin (esimerkiksi tutin tai ämpärin imeminen), veden juomisen aiheuttamaan ruuansulatuskanavan täyteisyyteen tai muihin palkitseviin tekijöihin juottosysteemissä.

\section{Vieroitusajankohta}

Sweeneyn ym. (2010) ja de Passillén ym. (2010) havaintojen perusteella vasikka ei pysty täysin sopeutumaan kuuden viikon iässä tapahtuvaan vieroitukseen. Sekä asteittain vieroitettujen että äkillisesti vieroitettujen runsaasti juotettujen vasikoiden kasvu heikkeni vieroituksessa, vaikka asteittain vieroitetut vasikat lisäsivät väkirehun syöntiä vieroituksen aikana (Sweeney ym. 2010). Kasvu kärsi etenkin vasikoilla, joilla asteittainen vieroitus alkoi varhaisimmin, 19 vrk iässä.

Runsaasti juotettujen vasikoiden on havaittu hyötyvän vieroituksen lykkäämisestä 12-13 viikon ikään (De Passillé ym. 2011). 12,5 viikon iässä vieroitetut vasikat söivät enemmän kiinteää rehua ja kasvoivat paremmin vieroituksessa ja välittömästi vieroituksen jälkeen kuin 7,5 viikon iässä vieroitetut vasikat. Myöhään vieroitetut vasikat olivat edelleen kokeen lopussa (15 viikon iässä) painavampia kuin aiemmin vieroitetut vasikat. Myöhäinen vieroitus myös vähensi nälästä kertovaa käyttäytymistä (vierailuja juottoautomaatilla) vieroituksen aikana.

Eräissä tutkimuksissa vieroitusajankohdan ei ole raportoitu vaikuttavan vasikoiden kasvuun. Kehoe ym. (2007) vertasivat niukasti juotettujen vasikoiden vieroitusta kolmen, neljän, viiden ja kuuden viikon iässä. Vieroitusajankohdalla ei ollut vaikutusta vasikoiden ensimmäisen kahdeksan viikon kasvuun ja terveyteen. Hopkins (1997) vertasi niukasti juotettujen vasikoiden vieroitusta neljän viikon ja kahdeksan viikon iässä. Vieroitusajankohdalla ei ollut vaikutusta vasikoiden painoon 180 vrk pituisen kokeen aikana.

Vieroitusajankohdan on havaittu vaikuttavan vasikoiden juoksuleikin määrään (Krachun ym. 2010). Juoksuleikki väheni voimakkaammin asteittaisessa vieroituksessa seitsemän viikon iässä vieroitetuilla vasikoilla kuin 13 viikon iässä vieroitetuilla vasikoilla. Lisäksi energiansaanti näytti vaikuttavan leikin määrään: energiansaannilla ja leikin määrällä havaittiin positiivinen korrelaatio vasikoiden seitsemän ja 13 viikon iässä. Steenin (1991) kokeessa vieroitusajankohdan vaikutus kasvuun tasoittui juottokauden jälkeen. Runsaasti juotetut, kuuden viikon iässä vieroitetut vasikat kasvoivat vieroituksen jälkeen 2,5 viikon ajan heikommin kuin 8,5 viikon iässä vieroitetut vasikat. Vasikoiden keskimääräisessä kasvussa kokeen aikana tai teurastuloksissa ei ollut eroa ryhmien välillä.

\section{Väkirehun syöntiin perustuva vieroitus}

Roth ym. (2009b) vertasivat niukasti juotetuilla vasikoilla tavanomaista asteittaista vieroitusta 56-84 vrk iässä ja väkirehun syöntiin perustuvaa asteittaista vieroitusta, joka alkoi vasikoiden syödessä väkirehua $700 \mathrm{~g} /$ vrk ja päättyi vasikoiden syödessä väkirehua $2000 \mathrm{~g} / \mathrm{vrk}$. Vieroitustavalla ei ollut vaikutusta vasikoiden kasvuun, terveyteen, ruumiinlämpöön tai eläinlääkärin tekemiin hoitoihin. Vieroitustavalla ei ollut tilastollisesti merkitsevää vaikutusta myöskään pötsin papillien pituuteen. Väkirehun syömiseen perustuvalla vieroitusmenetelmällä vasikat vieroitettiin kuitenkin keskimäärin aikaisemmin kuin tavanomaisella menetelmällä (76 vrk ikä vs. 84 vrk ikä). Roth ym. (2009b) päättelivät väkirehun syöntiin perustuvan vieroituksen mahdollistavan vasikan nopeamman fysiologisen kehityksen ilman negatiivisia vaikutuksia pötsin kehitykseen, kasvuun tai terveyteen. De Passillé \& Rushen (2012) raportoivat, että vieroituksen säätäminen yksilöllisesti vasikan kiinteän rehun syöntikyvyn mukaan voi aikaistaa vieroitusta ja samalla vähentää vieroituksen haittoja energian syönnille ja kasvulle runsaasti juotetuilla vasikoilla. 


\section{Yhteenveto ja johtopäätökset}

Runsaasti (vähintään 7,5 l/vrk) juotetut vasikat kasvavat juottokaudella paremmin kuin niukasti $(4,0$ 6,0 1/vrk) juotetut vasikat. Runsaasti juotettujen vasikoiden kasvu kuitenkin yleensä taantuu väliaikaisesti vieroituksessa, mikä heikentää suurella juottomäärällä saavutettavaa hyötyä. Nuorimpien vasikoiden on niukalla juotolla vaikea kompensoida vähäistä energian saantia kasvattamalla väkirehun syöntiä. Niukalla juotolla vasikat vierailevat useammin tuloksetta juottoautomaatilla, viettävät kaikkiaan juottoautomaatilla enemmän aikaa ja häiritsevät juovaa eläintä useammin kuin runsaalla juotolla. Vasikat siis jäävät nälkäisiksi niukalla juotolla. Niukka juotto myös vähentää vasikoiden leikkikäyttäytymistä. Juottomäärällä (jos yli 4,0 1/vrk) ei yleensä ole havaittu vaikutusta vasikoiden terveydentilaan.

Juottoautomaatin kapasiteetti pystytään hyödyntämään parhaiten juottamalla vasikoita runsaasti, jolloin yksittäisen vasikan juottoautomaatilla viettämä aika lyhenee. Joidenkin tutkimusten mukaan juottokauden hyvä ravitsemus ja kasvu voivat vaikuttaa myönteisesti hiehojen maitotuotokseen ensimmäisellä tuotoskaudella. Tosin useissa muissa tutkimuksissa vastaavaa yhteyttä ei ole havaittu. Hyvin niukka juotto (juomarehua 4 1/vrk) voi heikentää sonnien elinikäiskasvua.

Asteittainen vieroitus juoman määrää vähentämällä kannustaa vasikoita väkirehun syöntiin. Nuoret vasikat eivät kuitenkaan pysty täysin kompensoimaan maidon juonnin vähenemistä väkirehun syöntiä lisäämällä, mikä näkyy kasvun heikkenemisenä. Asteittainen vieroitus on kuitenkin parempi vieroitustapa kuin äkillinen vieroitus. Runsaasti juotetut vasikat voivat hyötyä portaittaisesta vieroituksesta, joka tapahtuu laimentamalla juomaa vedellä. Vieroitukseen liittyvää stressireaktiota voidaan lieventää tarjoamalla vasikalle edelleen pääsy juottolaitteelle juomaan lämmintä vettä muutaman päivän ajan vieroituksen jälkeen. Varhainen, kuuden viikon iässä tapahtuva vieroitus vaarantaa vasikoiden hyvinvoinnin: vieroituksessa vasikoiden kasvu heikkenee, juoksuleikki vähenee ja nälästä kertova käyttäytyminen lisääntyy. Vasikoiden kyvyssä siirtyä kiinteälle rehulle esiintyy suurta vaihtelua yksilöiden välillä. Väkirehun kulutukseen perustuva asteittainen vieroitus voi aikaistaa vieroitusta ilman negatiivisia vaikutuksia pötsin kehitykseen tai vasikan kasvuun ja terveyteen.

\section{Kirjallisuus}

Aikman, P.C., Gould, M. \& Bleach, E.C.L. 2007. First lactation milk yield and fertility of Holstein heifers reared using three milk replacer feeding regimes. J. Dairy Sci. 90 (Suppl. 1): 112 (Abstrakti).

Appleby, M. C., Weary, D. M. \& Chua, B. 2001. Performance and feeding behaviour of calves on ad libitum milk from artificial teats. Appl. Anim. Behav. Sci. 74: 191-201.

Bar-Peled, U., Robinson, B., Maltz, E., Tagari, H., Folman, Y., Bruckental, I., Voet, H., Gacitua, H. \& Lehrer, A.R. 1997. Increased weight gain and effects on production parameters of Holstein heifer calves that were allowed to suckle from birth to six weeks of age. J. Dairy Sci. 80: 2523-2528.

Borderas, T. F., de Passillé, A. M. B. \& Rushen, J. 2009. Feeding behaviour of calves fed small or large amounts of milk. J. Dairy Sci. 92: 2843-2852.

Budzynska, M. \& Weary, D. M. 2008. Weaning distress in dairy calves: Effects of alternative weaning procedures. Appl. Anim. Behav. Sci. 112: 33-39.

Daniels, K. M., McGilliard, M. L., Meyer, M. J., Van Amburgh, M. E., Capuco, A. V. \& Akers. R. M. 2009. Effects of body weight and nutrition on histological mammary development in Holstein heifers. J. Dairy Sci. 92: 499-505.

Davis Rincker, L., VandeHaar, M., Wolf, C., Liesman, J., Chapin, L. \& Weber Nielsen, M. 2006 Effects of an intensified compared to a moderate feeding program during the preweaning phase on long-term growth, age at calving, and the first lactation milk production. J. Dairy Sci. 84: 438 (Abstrakti).

de Passillé, A. M., Borderas, T.F. \& Rushen, J. 2011. Weaning age of calves fed a high milk allowance by automated feeders: effects on feed, water, and energy intake, behavioral signs of hunger, and weight gains. J. Dairy Sci. 94: 1401-1408.

de Passillé, A.M., \& Rushen, J. 2012. Adjusting the weaning age of calves fed by automated feeders according to individual intakes of solid feed. J. Dairy Sci.: 5292-5298.

de Passillé, A. M., Sweeney, B \& Rushen, J. 2010. Cross-sucking and gradual weaning of dairy calves. Appl. Anim. Behav. Sci. 124: 11-15.

De Paula Vieira, A., Guesdon, V., de Passillé, A. M., von Keyserlingk, M. A. G. \& Weary, D. M. 2008. Behavioural indicators of hunger in dairy calves. Appl. Anim. Behav. Sci. 109: 180-189.

Drackley, J. K, Pollard, B.C., Dann, H. M. \& Stamey, J. A. 2007. First-lactation milk production for cows fed control or intensified milk replacer programs as calves. J. Dairy Sci. 90 (Suppl. 1): 614 (Abstrakti).

Evira, 2013. Luomutuotanto 2, Eläintuotannon ehdot. Eviran ohje 18217/3. 3. painos. 46 s. 
Foldager, J. \& Krohn, C.C. 1994. Heifer calves reared on very high or normal levels of whole milk from birth to 6-8 weeks of age and their subsequent milk production. Proc. Soc. Nutr. Phys. 3: 301.

Fröberg, S., Lidfors, L., Svennersten-Sjaunja, K. \& Olsson, I. 2011. Performance of free suckling dairy calves in an automatic milking system and their behaviour at weaning. Acta Agric. Scand., Sect. A, Anim. Sci. 61: $145-156$.

Hopkins, B. A. 1997. Effects of the method of calf starter delivery and effects of weaning age on starter intake and growth of holstein calves fed milk once daily. J. Dairy Sci. 80: 2200-2203.

Huuskonen, A. \& Khalili, H. 2008. Computer-controlled milk replacer feeding strategies for group-reared dairy calves. Livest. Sci. 113: 302-306.

Huuskonen, A., Huumonen, M., Joki-Tokola, E. \& Tuomisto, L. 2011. Effects of different liquid feeding strategies during the pre-weaning period on the performance and carcass characteristics of dairy bull calves. Acta Agric. Scand., Sect. A, Anim. Sci. 61: 187-195.

Jasper, J. \& Weary, D. M. 2002. Effects of ad libitum milk intake on dairy calves. J. Dairy Sci. 85: 3054-3058. Jasper, J., Budzynska, M. \& Weary, D.M. 2008. Weaning distress in dairy calves: Acute behavioural responses by limit-fed calves. Appl. Anim. Behav. Sci. 110: 136-143.

Jensen, M. B. 2006. Computer-controlled milk feeding of group-housed calves: the effect of milk allowance and weaning type. J. Dairy Sci. 89: 201-206.

Jung, J. \& Lidfors, L. 2001. Effects of amount of milk, milk flow and access to a rubber teat on cross-sucking and non-nutritive sucking in dairy calves. Appl. Anim. Behav. Sci. 72: 201-213.

Kehoe, S. I., Dechow, C. D. \& Heinrichs, A. J. 2007. Effects of weaning age and milk feeding frequency on dairy calf growth, health and rumen parameters. Livest. Sci. 110: 267-272.

Kemppi, H. 2005. Ternimaito / täysmaito / juottorehujuoma. Teoksessa: Vasikoiden hoito-opas. Korjattu painos 2005. s. 23-28.

Khalili, H, Rinne, M., Aspila, P. \& Aronen, I. 2004. The effect of free or restricted acidified milk feeding of Finnish Ayrshire bull calves on the subsequent fattening and slaughter performance Agric. Food Sci. 13: 247255.

Khan, M. A., Lee, H. J., Lee, W. S., Kim, H. S., Kim, S. B., Ki, K. S., Ha, J. K., Lee, H. G. \& Choi, Y. J. 2007. Pre- and postweaning performance of holstein female calves fed milk through step-down and conventional methods. J. Dairy Sci. 90: 876-885.

Krachun, C., Rushen, J. \& de Passillé, A. M. 2010. Play behaviour in dairy calves is reduced by weaning and by a low energy intake. Appl. Anim. Behav. Sci. 122: 71-76.

Morita, S., Sugita, S., Yamamoto, M., Hoshiba, S. \& Uemura, T. 1999. Behavioral investigation of group rearing calves in automatic milk replacer feeding system. Anim. Sci. J. 70: 542-546.

Morrison, S. J., Wicks, H. C. F., Fallon, R. J., Twigge, J., Dawson, L. E. R., Wylie, A. R. G. \& Carson, A. F. 2009. Effects of feeding level and protein content of milk replacer on the performance of dairy herd replacements. Animal 3: 1570-1579.

Nielsen, P. P., Jensen, M. B. \& Lidfors, L. 2008a. Milk allowance and weaning method affect the use of a computer controlled milk feeder and the development of cross-sucking in dairy calves. Appl. Anim. Behav. Sci. 109: 223-237.

Nielsen, P. P., Jensen, M. B. \& Lidfors, L. 2008b. The effects of teat bar design and weaning method on behavior, intake, and gain of dairy calves J. Dairy Sci. 91: 2423-2432.

Quigley, J. D., Wolfe, T. A. \& Elsasser T. H. 2006. Effects of additional milk replacer feeding on calf health, growth, and selected blood metabolites in calves. J. Dairy Sci. 89: 207-216.

Raeth-Knight, M., Chester-Jones, H., Hayes, S., Linn, J., Larson, R., Ziegler, D. \& Ziegler, B., Broadwater, N. 2009. Impact of conventional or intensive milk replacer programs on Holstein heifer performance through six months of age and during first lactation. J. Dairy Sci. 92: 799-809.

Roth, B. A., Keil, N. M., Gygax, L. \& Hillmann, E. 2009a. Temporal distribution of sucking behaviour in dairy calves and influence of energy balance. Appl. Anim. Behav. Sci. 119: 137-142.

Roth, B. A., Keil, N. M., Gygax, L. \& Hillmann E. 2009b. Influence of weaning method on health status and rumen development in dairy calves. J. Dairy Sci. 92: 645-656.

Shamay, A., Werner, D., Moallem, U., Barash, H. \& Bruckental, I. 2005. Effect of nursing management and skeletal size at weaning on puberty, skeletal growth rate, and milk production during first lactation of dairy heifers. J. Dairy Sci. 88: 1460-1469.

Steen, R. W. J. 1991. The effect of milk substitute input during calfhood on the lifetime performance of beef cattle. Anim. Prod. 52: 67-74.

Sweeney, B. C., Rushen, J., Weary, D. M. \& de Passillé, A. M. 2010. Duration of weaning, starter intake, and weight gain of dairy calves fed large amounts of milk. J. Dairy Sci. 93: 148-152.

Vasseur, E., Borderas, F., Cue, R. I., Lefebvre, D., Pellerin, D., Rushen, J., Wade, K. M. \& de Passillé, A. M. 2010. A survey of dairy calf management practices in Canada that affect animal welfare. J. Dairy Sci. 93: 1307-1315. 